\title{
The character of demand in mature organic food markets: Great Britain and Denmark compared
}

\author{
Mette Wier, FOI \\ Katherine O’Doherty Jensen, KVL \\ Laura Mørch Andersen, AKF, \\ Katrin Millock, CIRED, \\ and \\ Lars Rosenkvist, FOI
}




\begin{abstract}
We investigate the organic food market in two selected European countries, Great Britain and Denmark, identifying main differences and similarities. We focus particularly on consumer preferences and priorities, labelling schemes, supply and sales channels, as a basis for assessing market stability and prospects for future growth. We employ a unique set of household panel data that includes information on stated values and concerns, as well as registered purchasing behaviour. Most organic food on both markets is produced and processed by large-scale industrialised units and distributed through concentrated mainstream sales channels, consumer confidence being sustained at present by organic labelling schemes that appear to function well. However, a parallel market, based on various types of direct sales to heavy users, prevails. We find that organic food purchase decisions are primarily motivated by 'private good' attributes such as freshness, taste and health benefits, attributes that may be perceived as being compatible with modern production and sales structure. More traditional 'public good' organic attributes, such as environmental and animal welfare attributes, small scale production and local supply, are less compatible with current market structure, but are also accorded less priority by the majority of consumers in practice. Mature markets for organic foods nevertheless may constitute a source of consumer dissatisfaction, particularly in the group of organic heavy users.
\end{abstract}




\section{Introduction}

The market for organic foods is developing fast throughout Europe (Hamm et al, 2002; Wier and Calverley, 2002). Two relatively mature markets, Great Britain and Denmark, are especially interesting in this context. Britain has the most rapidly growing market, while Denmark has the highest consumption of organic food per capita in Europe (Morgan and Murdoch, 2000, Hamm et al., 2002). The British and Danish markets for organic foods share several important features. These markets function well and do not suffer seriously from supply shortages or other barriers that frequently hinder market development in other countries (Torjusen et al., 2004).

On the demand side, the recent growth in consumption of organic foods may be due to an increasing focus on the 'private' attributes of goods, such as health, taste and quality. In addition, increasing food safety concern, partly nurtured by the threat of food scares emerging during the 1990s, appears to play a role (see e.g. Beckmann, 2001; Briz and Al-Hajj, 2003; Mitchell, 1998; Richter et al., 2000, Storstad and Bjørkhaug, 2003). However, if demand for organic foods is increasingly driven by food safety concern, the structure of the modern organic market may represent a paradox. Organic farming has been traditionally viewed as representing a critical stance towards increasingly industrialised conventional farming (see e.g. Morgan and Murdoch, 2000). Earlier research has shown that organic farmers differ considerably from conventional farmers with regard to their attitudes towards environmental and animal welfare issues (Storstad and Bjørkhaug, 2003). Organic products have been frequently associated with attributes such as traceability, local origin and supply, small scale units of production, adequate information through the chain from producer to consumer, all characteristics commonly associated with foods that are perceived as being safe and trustworthy. Nevertheless, the market structure of the organic food sector in Britain and Denmark today does not differ significantly from the conventional food sector, and lacks several of these features. Both markets are based on highly industrialised and concentrated units of production, distributed through mainstream retail channels. Organic products on both markets are sometimes highly processed, often imported, and consumer access to information about producers is frequently limited. Consumer dissatisfaction with these market features may underlie the recent growth of box schemes and other direct sales channels in both countries.

In this paper, we will describe the features of the British and Danish organic food markets in more detail, identifying to what extent food safety and other concerns influence demand. We will also discuss the ways in which organic production, consumer concerns and increasing industrialisation and market concentration appear to act together. Our study distinguishes itself by being based on household level observations of stated views as well as registered behaviour regarding purchases of a large number of organic as well as conventional foods, which makes possible a detailed and informative analysis. Since data on observed market behaviour have not been available in any country until recently, almost no studies of demand estimates for organic foods based on actual purchases have been published previously. The few exceptions are Brombacher (1992), Armand-Balmat (2002), Glaser and Thompson (1998, 2000) and 
Jörgensen (2001), who all use sales data or bar code scanner data from Marketing Research Institutes from Germany, USA and Sweden, respectively. Almost all other previous studies on organic foods are based solely on postulated behaviour, i.e. stated willingness to pay (see e.g. Beharrell and MacFie, 1991; Bugge and Wandel, 1995; CMA, 1996; Coopers and Lybrand Deloitte, 1992; Drake and Holm, 1989; Fricke, 1996; Grunert and Kristensen, 1995; Jolly, 1991; Krämer et al., 1998; Misra et al., 1991). However, stated willingness to pay may not reflect actual behaviour (Cook 1991; Kramer 1990; Carson et al. 1996; Cummings et al., 1995; Frykblom, 1997; Hansen and Sorensen, 1993).

\section{Methods and data}

Consumer utility is derived from consumption of goods, or rather from specific characteristics or quality attributes of goods. Following Lancaster (1994), each good can be distinguished by different characteristics in different proportions, i.e. bundles of attributes. Some attributes are product specific (taste, freshness, texture, nutrients of benefit to health, etc) and can only be enjoyed when eating a specific product. Other attributes, however, may be perceived as "general", in the sense that they are offered by one good as well as by another. In the case of organic goods, this may hold for attributes such as animal welfare, environmental attributes and to some extent health attributes. The consumer may wish to reduce environmental loading, for example, by purchasing both bread and apples from environmentally friendly production units.

In the following, we distinguish various types of product attributes or more general values or benefits. First, we distinguish between 'private' and 'public' goods. Private goods can only be consumed by one household (e.g. an organic potato can only be eaten once, in one household). In contrast, public goods can be shared (held in common), such that the utility of their consumption by any one household is independent of (and does not exclude) consumption by other households.

Second, consumers who actually purchase organic foods (buyers) may obtain 'use values', such as utility from taste, health and freshness, i.e. private good attributes, which can only be enjoyed by actually consuming (eating) the product. In our study, 'non-use values' are defined as public good values related to improved environment and/or animal welfare. Other non-use values, not directly treated in this study, are existence value (utility from knowing organic farming exists), vicarious value (utility from indirect consumption, e.g. reading about or watching a television program on organic farming), bequest value (utility from preserving organic farming for future generations), and altruistic value (utility from knowing other households are achieving utility). Finally, a further type of value is the 'option price', i.e. the value of having the possibility of consuming organic foods at some time in the future. For more on value types, see e.g. Freeman (1993).

To test significant differences between user groups, we apply the Likelihood Ratio test for independence in the cross tabulation of responses to specific questions by buyer/non-buyer status. The test compares the observed distribution with the expected distribution under the assumption that the answers are 
independent of buyer/non-buyer status. To explain actual purchasing behaviour, we apply econometric household level demand modelling. We have employed three different modelling approaches in our analyses. For reasons of brevity, only one of these is reported here, the others having been documented in Hansen (2005), Wier et al. (2005), and Millock et al. (2004). ${ }^{1}$

With respect to demand in Britain, we employ household panel data provided by the market research institute TNS, encompassing the daily purchases of 15,000 households. These data include approximately $90 \%$ of all household grocery shopping by these households. We have access to purchase data for 5 product types (organic/non-organic weekly purchases of milk, eggs, yoghurt, fruit and vegetables) during 2001-2003. The data include household level information on expenditure and volume, as well as total basket expenditure and store choice for each of the 5 product categories. Approximately $20 \%$ of the sample is replaced each year, and the panel is continuously balanced to ensure that it is (geographically and demographically) representative of the British population. However, this is not fully achieved, the upper middle class being notably underrepresented. (See Appendix A for information on the demographic profile of the sample.) The panel members record the items purchased on every shopping trip using a barcode laser scanner. In addition to the purchase data, we have access to background information, including social class, presence of children, household size, age of key household shopper, and geographical region. Finally, we have access to the Top20 statements that are most frequently agreed with among organic buyers, as compared to the average household shopper. However, it is important to note that this information is only available on an aggregated level, ruling out analyses that correlate this information with purchasing behaviour at the household level.

With respect to Denmark we employ household panel data provided by the market research institute GfK Denmark, encompassing more than 2,000 households' purchases of daily necessities during 1997-2001. These data include approximately $80 \%$ of all grocery shopping in these households. Approximately $20 \%$ of the sample is replaced each year, and the panel is continuously balanced to ensure that it is representative of the Danish population. An analysis of this sample is reported in Andersen (2002), concluding that the panel is representative. All data are self-reported. Each household fills in a shopping diary, which is collected and checked by GfK Denmark at regular intervals. The households report product characteristics at a detailed level (type, brand, scanner-code, volume, units, price, organic/non-organic), as well as store choice, and date and time of each shopping trip. In addition to these data, we have access to background information regarding household composition, including age, gender, education, occupation and income of all household members, as well as geographical location, type and ownership of the home. More information about the sample can be found in Andersen (2001, 2002). (See also Appendix A for information on the demographic profile.)

\footnotetext{
${ }^{1}$ Similar results are found when using other modelling approaches. In earlier analyses of these data, we have employed Logit modelling (Millock et al, 2004), in which the probability of being in a specific buyer group using same explanatory variables was estimated, as well as a micro-econometric demand model to explain organic budget shares, in which each household's deviation from the average demand for organic foods is estimated as a household specific constant term (Hansen, 2004).
} 
The Danish purchase data are supplemented by survey data obtained by questionnaire and addressed to all households in the same GfK panel. Information regarding attitudes, perceptions, values and food habits were obtained from 1609 households, corresponding to a response rate of 77\%. (Further information about the demographic profile of this sample is included in Appendix A.) The survey focussed particularly on perceptions and stated valued attributes with respect to organic foods. It is the combination of these two sources of information (purchase data and questionnaire data) from the same households that makes our data set unique.

\section{User groups}

Dividing consumers into four groups according to the size of their organic budget share (defined as the ratio of organic food expenditure to total food expenditure) provides information about differences between buyer groups. We define heavy users as consumers having an organic budget share (all food types) higher than $10 \%$, medium users as consumers having an organic budget share between $2.5 \%$ and $10 \%$, light users as consumers having an organic budget share lower than $2.5 \%$, and finally non-users as consumers who do not purchase organic goods at all.

On the British market, the average household organic budget share increased rapidly, especially during 2001 and 2002, when it increased from 2.4\% to 2.8\%. In 2003, the budget share stagnated at the $2.8 \%$ level. Non-users and light users constituted almost equally large groups of households at the beginning of the observation period, but by 2003 the relative number of non-users had increased to 45\% (of all households in the panel), while light users had decreased to $38 \%$. Approximately $13 \%$ of all households are medium users, while approximately $4.5 \%$ are heavy users - the number of households in both groups (in particular medium users) having increased during the observation period.

In comparing these data with Danish data, it is important to note that for British households we have access to purchase data for the 5 most sold organic products (during 2001-2003), while for Danish households we have access to information on the whole consumer basket (during 1997-2001). With this reservation, it must nevertheless be said that several differences are apparent. The most important difference is that the average organic household budget share in Denmark is substantially higher and, correspondingly, medium and heavy users constitute a greater proportion of all households, as illustrated in Figure 1. The budget share increased continuously until 1999, fluctuated for a couple of years and then settled back at the 1998-level (the boldest line in Figure 1). In 2001, almost every second Danish household (48\%) was a light user and 28\% were medium users. Only 10\% never purchased organic foods, while $14 \%$ had a very high consumption (heavy users). The relative number of non-users had decreased continuously during 1997-2001, while more consumers had become medium and heavy users during the period. 
Figure 1. Average organic budget share and distribution of user types

\section{Great Britain, 2001-2002}

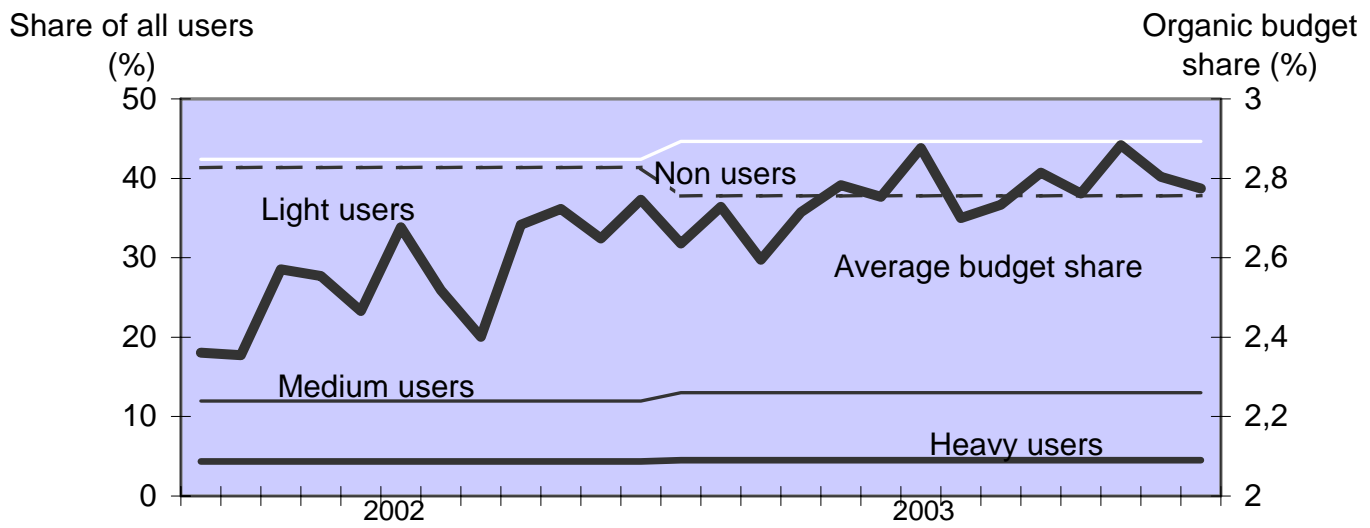

Note: Average organic budget share is calculated monthly. Share of all users is calculated yearly.

\section{Denmark, 1997-2001}

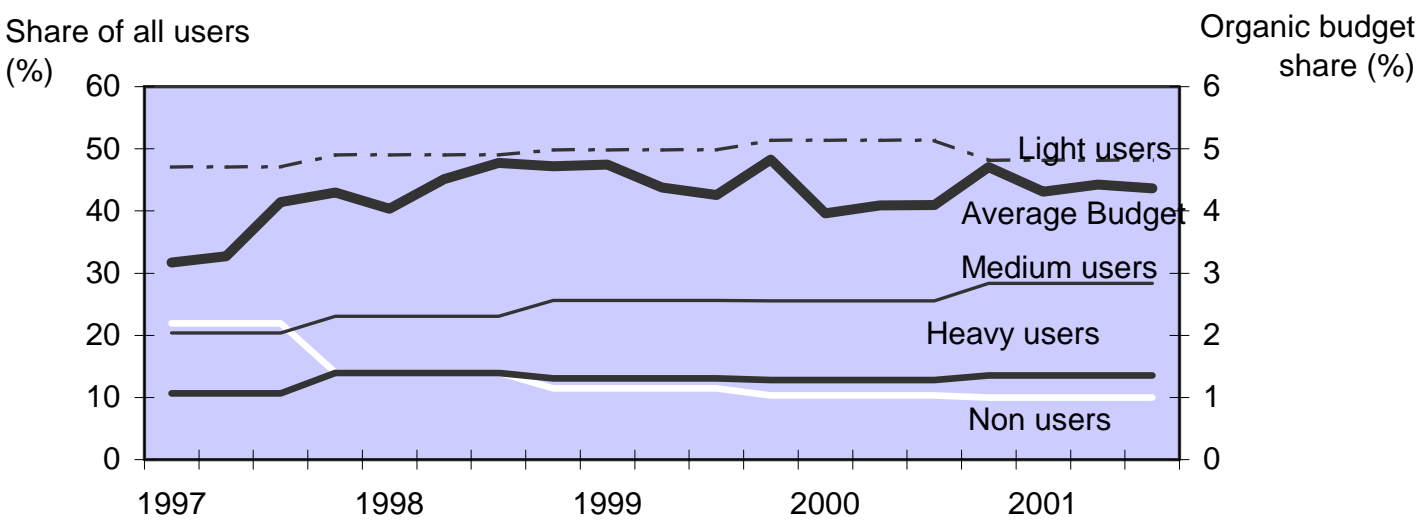

Note: Average organic budget share is calculated quarterly. Share of all users is calculated yearly.

Source: Own calculations based on GfK purchase data 1997-2001 and TNS purchase data July 2002 to July 2003.

These changes in consumption of various organic products can be broken down by changes in the behaviour of specific user groups. Average organic budget shares have been relatively stable within each user group during the whole observation period in Denmark. For Great Britain on the other hand, average organic budget shares had increased within each user group. This holds true especially for heavy users, among whom the budget share increased from 23.4\% to 25.3\% during 2001-2003.

However, very interestingly, each user group does not comprise the same households during the periods of observation. A significant number of households move from one group to another. Weatherell et al. (2003) suggest that consumers appear to change concerns and attitudes over time - and that consumer choices are capricious, as more pragmatic priorities and trade-offs are prevalent and frequently influence purchasing decisions. This pattern of changing purchasing behaviour is highly confirmed in our study. 
Thus, for Great Britain, our purchase data reveal that by 2003 one fourth of those who were heavy users in 2001 had become medium users, 7\% had become light users and, very surprisingly, one fifth had become non-users. However, since new heavy users had continuously turned up, the heavy user group nevertheless constituted a slightly increasing proportion of all consumers, and furthermore contributed to an increasing overall average organic budget share, as mentioned above.

Correspondingly, around one fifth of those who were non-users in 2001, had become either light, medium or heavy users by 2003. Considerable movements are observed in the other two groups as well, in which the largest shift was to the non-user group, around one fourth had stayed in the same group, while the remainder had merged into other user groups.

Turning to the Danish households, our estimates reveal that around one third of those who were heavy users in 1997 had turned into medium users by 2001, and even (although to a lesser extent) light users. In fact, the sub-group of households that comprised heavy users in 1997 was the group that had reduced their demand for organic foods most (compared to other households in the panel). Essentially, households that left the heavy user group were responsible for a considerable part of the decreasing organic demand during 1999. However, since new heavy users continuously turned up, the heavy user group constituted a slightly increasing proportion of all consumers, and this group exhibited a stable overall average organic budget share during 1997-2001.

Similarly, Danish households that were non-users in 1997 had increased their demand for organic foods considerably. Accordingly, more than half of these households had already become light or even medium users by 1999. However, from 1999-2001, no such major change occurred. In addition, the households that were light and medium users in 1997 had increased their demand for organic products continuously until 1999, such that a significant proportion had become new heavy users. But again, as new households entered the groups of light and medium users, these constituted an increasing share of all households, and their average organic budget share remained relatively stable. .

\section{Product groups}

Underlying average aggregated developmental trends, considerable differences regarding demand for specific product groups can be observed. In Denmark, the reduced overall market share for organic foods during 1999 was primarily due to decreasing demand for organic meat, bread and cereal products, as well as dairy products such as butter, yoghurt and cheese. In contrast, the consumption of organic milk and coffee had increased, while demand for organic eggs, fruit and vegetables remained relatively stable during the period. In Great Britain, the organic budget share had increased continuously for all products. Highest growth rates are observed for organic milk, eggs, and yoghurt (in that order), while the relative growth in consumption of organic fruit and vegetables is lower.

In both countries, organic budget shares vary considerably across product groups. Table 1 presents organic sales of the most sold organic products, British estimates on the left half of the table, Danish 
on the right. Once again, it should be noted that for Danish households, we have had access to information on the whole consumer basket, while for British households, we have only had access to purchase data for the 5 most sold organic products. The most recent year for which data are available is shown for both countries. The first column (in each half) shows the average organic budget share by product group. The second column shows the share of total organic sales by product group, and finally the remaining columns show the organic budget share by user groups.

Table 1 Average organic budget shares by user and product groups (\%), Britain and Denmark

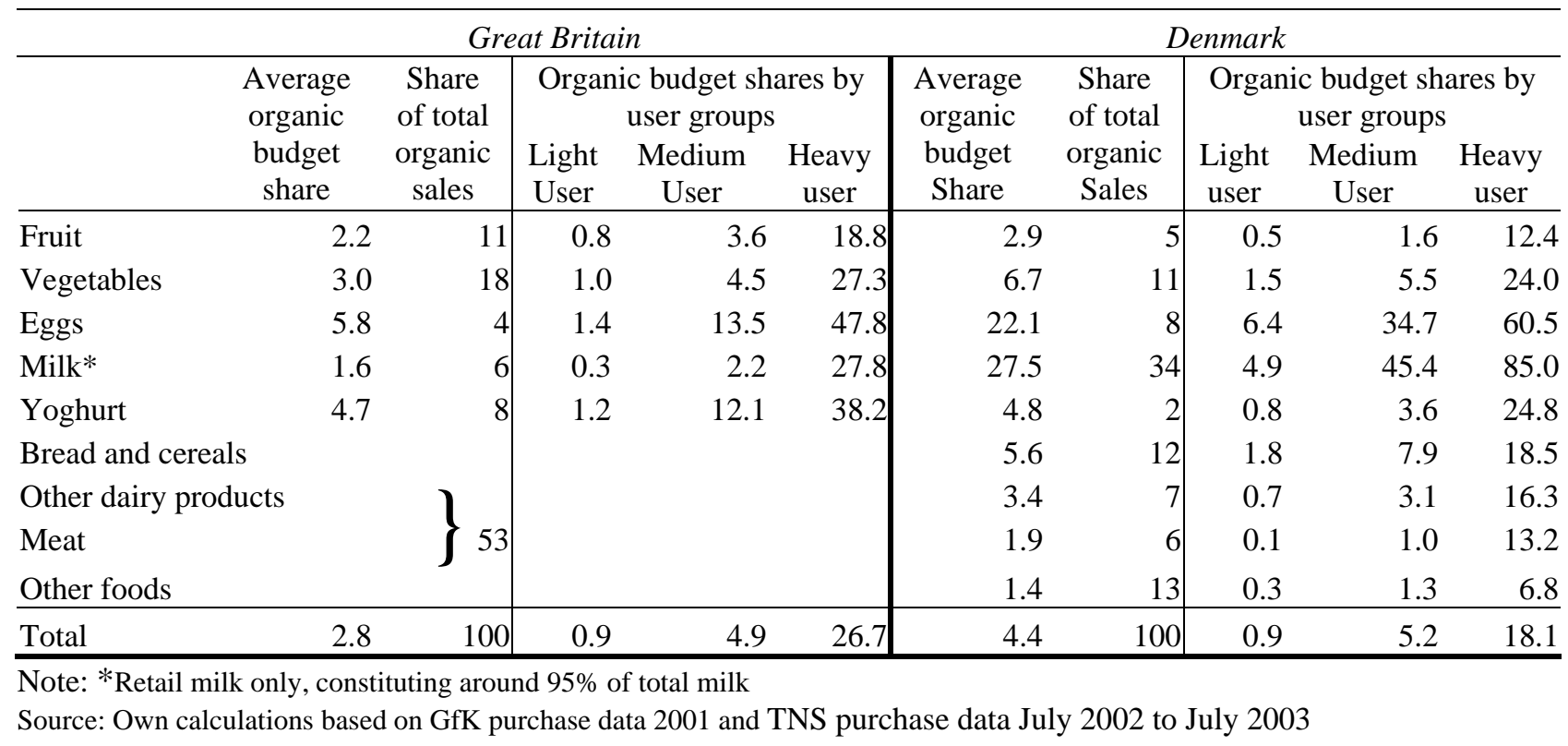

Danish organic budget shares are generally much higher than British - on average $60 \%$ higher. Moreover, the variation across product groups in Danish budget shares is much larger, spanning from around $1 \%$ to more than $27 \%$ (for milk). In comparison, the highest average British budget share is less than 6\% (for eggs). In Great Britain, the highest average organic budget shares are observed for eggs and yoghurt, while in Denmark, the highest organic budget shares are observed for milk and eggs. Fruit and yoghurt have approximately the same average organic budget shares in both countries, but consumption of these goods constitutes a much higher share of total organic consumption in Britain than in Denmark. The most important organic product groups in Britain are vegetables and fruit, which together constitute more than half of total organic sales. The most important product groups in Denmark are milk and cereals, constituting almost half of total organic consumption.

Table 1 also reveals differences between user groups. For British households, the highest share is observed for eggs, for which heavy users hold an organic budget share of $48 \%$. For Danish households, the highest budget share is observed for milk, for which heavy users display a budget share of 85\%. Light and medium users appear to spend approximately the same average organic budget share in both 
countries (see all products, last row). However, British heavy users appear to have a considerably higher organic budget share than do Danish heavy users. This pattern, however, is mainly due to the fact that the British purchase data cover the five most sold organic products, while the Danish data cover the whole consumer basket.

Table 2 shows the distribution of the total organic sales of products among user groups, and the corresponding average price premium for organic products (as compared to conventional variants of the same product). Please note that the Danish price premiums are mix corrected, which is to say they are corrected for differences in product mix between organic and conventional consumption within this product group (see table note). Unfortunately, this is not possible for the British price premiums, since we have no information on quality variations within each product group.

Table 2. Organic sales and price premiums by user groups

\begin{tabular}{|c|c|c|c|c|c|c|c|c|}
\hline & \multicolumn{8}{|c|}{ Organic sales by user groups (\%) } \\
\hline & \multicolumn{4}{|c|}{ Great Britain**** } & \multicolumn{4}{|c|}{ Denmark } \\
\hline & $\begin{array}{l}\text { Light } \\
\text { user }\end{array}$ & $\begin{array}{l}\text { Medium } \\
\text { user }\end{array}$ & $\begin{array}{c}\text { Heavy } \\
\text { User }\end{array}$ & $\begin{array}{c}\text { Organic } \\
\text { price } \\
\text { premium } * *\end{array}$ & $\begin{array}{l}\text { Light } \\
\text { user }\end{array}$ & $\begin{array}{l}\text { Medium } \\
\text { User }\end{array}$ & $\begin{array}{c}\text { Heavy } \\
\text { User }\end{array}$ & $\begin{array}{l}\text { Organic } \\
\text { price } \\
\text { premium* }\end{array}$ \\
\hline Fruit & 18 & 24 & 58 & 1.25 & 9 & 17 & 74 & 1.43 \\
\hline Vegetables & 16 & 22 & 61 & 1.73 & 11 & 25 & 64 & 1.31 \\
\hline Eggs & 10 & 33 & 56 & 2.33 & 15 & 45 & 40 & 1.40 \\
\hline Milk*** & 8 & 15 & 76 & 1.40 & 9 & 43 & 48 & 1.15 \\
\hline Yoghurt & 13 & 35 & 52 & 1.24 & 9 & 23 & 68 & 1.13 \\
\hline Bread and cereals & & & & & 17 & 38 & 45 & 1.36 \\
\hline Other dairy products & & & & & 11 & 26 & 63 & 1.35 \\
\hline Meat & & & & & 4 & 15 & 82 & 1.28 \\
\hline Other foods & & & & & 11 & 28 & 61 & 1.46 \\
\hline Total & 15 & 25 & 60 & & 11 & 34 & 56 & \\
\hline
\end{tabular}

Notes:

* Average price premium is corrected for differences in product mix between organic and conventional consumption within this product group. The price premium is estimated for the organic consumer basket. This is necessary, since organic variants of a large number of conventional products are not supplied on the market. However, average price premium is only partly corrected for differences in product mix between organic and conventional consumption within any product group, since all quality differences are not observable on the basis of our data. .

** Average price premium is not mix corrected. Our Danish data indicate that, in general, non-mix corrected price premiums are underestimated. If this holds for British data as well, the price premium estimates in this Table indicate a lower boundary, "true” mix corrected price premiums being possibly higher.

*** Retail milk only

**** Please note that part of direct sales/specialist shops sales may be underestimated in the TNS purchase data set ( $c f$. Section 5). This means that the distribution of user groups is associated with some uncertainty, due to variations in store choice between user groups.

Source: Own calculations based on GfK purchase data 2001 and TNS purchase data July 2002 to July 2003

In Britain, organic milk is primarily purchased by heavy users, while in Denmark, organic milk is a product purchased by medium users all well as heavy users. This is partly reflected in the fact that 
the average price premium for organic milk is considerably higher in Britain than in Denmark. Generally, heavy users are willing to pay higher absolute prices for organic as well as conventional goods, and furthermore they pay higher price premiums than do medium and light users (data not shown).

For fruit, vegetables, eggs, and yoghurt, British medium and light users are responsible for between 39\% (vegetables) and 48\% (yoghurt) of total organic consumption. The highest British price premiums for organic products are observed for eggs, vegetables and milk. Lowest premiums are observed for fruit and yoghurt. British light users are generally responsible for a higher share of total consumption than are Danish light users, and this holds especially for fruit and vegetables.

In Denmark, medium and light users together account for more than half of total organic consumption of eggs, bread and vegetables, as well as milk. They hold lower average organic budget shares than do heavy users (as shown in Table 1), but since they also constitute a large fraction of all consumers, they contribute considerably to total consumption. In contrast, organic fruit, vegetables, yoghurt and other dairy products, as well as meat, are primarily purchased by heavy users in Denmark.

The highest premiums in Denmark are observed for organic fruit - a product group purchased primarily by heavy users. Even though heavy users in both countries are on average willing to pay higher price premiums than medium and light users, this relationship is not unambiguous - as revealed in Table 1. One reason for this may be unobservable quality differences between organic and conventional variants within each product group, which is also partly reflected in the fact that heavy users are willing to pay higher absolute prices for organic as well as conventional goods (data not shown in Table 2).

\section{Sales channels}

In Great Britain, as well as in Denmark, most organic foods are sold through mainstream retail channels, and in both countries, organic foods are sold by all major retailers. Moreover, organic sales are concentrated around a few large multiples. According to our purchase data, three multiples (Tesco, Sainsbury and Waitrose,) are responsible for $70 \%$ of total organic sales in Great Britain, while two multiples (Coop Denmark and Dansk Supermarked) are responsible for $64 \%$ of total organic sales in Denmark. Supermarkets generally hold a much lower share of organic sales in almost all other European countries. Instead, direct sales and specialist shops constitute on average $50 \%$ of all organic sales on the European market, and in some countries more than $80 \%$ (Synergie, 2002; Hamm et al., 2002).

Table 3 shows the total organic sales of the main organic products by retail sales channels, revealing that $95 \%$ of British organic foods are sold in supermarkets. ${ }^{2}$ In Denmark, on average 58\% of all organic products are sold in supermarkets. Very interestingly, and quite exceptionally in an international

\footnotetext{
${ }^{2}$ Please note that the estimated share of supermarkets sales is much higher than estimates from other sources. In Hamm et al., 2002, this estimate is $79 \%$. Direct sales/specialty shop sales may be underestimated in the TNS purchase data. One possible explanation is that the panel members record items purchased from every shopping trip using a barcodes laser scanner, which may not be possible for items purchased at markets, for example. The Soil Association (www.soilassociation.org) estimates that in 2001-2002, approximately $10 \%$ of all organic goods were sold through direct sales channels.
} 
context, the second largest sales channel is discounters, which account for $25 \%$ of all sales of organic products. Finally, 15\% are purchased through direct sales (farm gates, box schemes, street stalls in urban areas, etc) or specialty stores (e.g. baker, butcher, greengrocer, health store). The remaining $2 \%$ are purchased through other sales channels such as

Table 3. Organic sales by sales channels and product groups in Great Britain ${ }^{1}$ and Denmark

\begin{tabular}{|c|c|c|c|c|c|c|c|c|}
\hline & \multicolumn{4}{|c|}{ Great Britain $^{1}$} & \multicolumn{4}{|c|}{ Denmark } \\
\hline & \multicolumn{4}{|c|}{ Share of total organic sales sold in } & \multicolumn{4}{|c|}{ Share of total organic sales sold in } \\
\hline & $\begin{array}{l}\text { Super- } \\
\text { Markets }\end{array}$ & $\begin{array}{l}\text { Discoun- } \\
\text { ters }\end{array}$ & $\begin{array}{l}\text { Specialty } \\
\text { /Direct sales }\end{array}$ & $\begin{array}{c}\text { Other sales } \\
\text { Channels }\end{array}$ & $\begin{array}{l}\text { Super- } \\
\text { Markets }\end{array}$ & $\begin{array}{l}\text { Discoun- } \\
\text { ters }\end{array}$ & $\begin{array}{l}\text { Specialty } \\
\text { /Direct sales }\end{array}$ & $\begin{array}{l}\text { Other sales } \\
\text { Channels }\end{array}$ \\
\hline Fruit & 96 & 0 & 2 & 2 & 55 & 14 & 24 & 7 \\
\hline Vegetables & 95 & 0 & 3 & 1 & 33 & 23 & 36 & 8 \\
\hline Eggs & 94 & 0 & 4 & 2 & 57 & 31 & 11 & 1 \\
\hline Milk & 94 & 1 & 2 & 3 & 64 & 35 & 0 & 1 \\
\hline Yoghurt & 96 & 1 & 2 & 2 & 86 & 12 & 1 & 1 \\
\hline Bread and cereals & & & & & 61 & 27 & 10 & 1 \\
\hline Other dairy products & & & & & 67 & 22 & 9 & 1 \\
\hline Meat & & & & & 19 & 3 & 77 & 1 \\
\hline Other foods & & & & & 70 & 15 & 12 & 4 \\
\hline Total & 95 & 1 & 3 & 2 & 58 & 25 & 15 & 2 \\
\hline
\end{tabular}

Source: Own calculations based on GfK purchase data 2001 and TNS purchase data July 2002 to July 2003

kiosks, petrol stations or small general stores. Quite interestingly, comparisons with the sales channels through which conventional foods are distributed, reveal that their distribution follows a similar pattern (data not shown ) - and this holds true for both countries. The fraction of sales through specialty shops, direct sales and other sales channels is moderately higher for organic foods compared to conventional foods in Denmark, but not in Great Britain.

Considerable differences are observed between product groups in Denmark. Some products are solely or almost solely sold in supermarkets (including discounters). This holds for milk, yoghurt and most cereals. In contrast, eggs, bread, vegetables, fruit and, in particular, various types of meat, are sold to a large extent through direct sales channels and specialty shops. Thus, in both countries, the major sales channel is supermarket sales (including discounters). Moreover, this form of distribution seems to constitute an important precondition for ensuring high market shares for organic products. A number of studies (Sylvander, 1995; Bugge and Wandel, 1995; CMA, 1996; Krämer et al., 1998; Menghi, 1997;) note that one of the most substantial barriers to the penetration of organic goods is that it is difficult for consumers to locate and identify organic commodities when only a few organic products are regularly on sale in supermarkets. While considerable parts of the European market for organic products suffer from insufficient supplies, the distribution of organic products in Europe is to an increasing extent being taken over by conventional distribution channels for sale in supermarkets. Besides Denmark and Great Britain, this is especially true for Sweden, Austria, and Finland, where relatively few conventional retail chains and organic food distributors dominate the market (Hamm et al., 2002). 
Results from Giraud (2003), Hamm et al. (2002) and Michelsen et al. (1999) suggest that average price premiums fall in accordance with increasing volume of supplies and increasing sales through supermarkets. A number of studies indicate that price premiums have to be lower than $20-30 \%$ before organic products loose their niche status (Beharrell and MacFie 1991; Bjerke 1992; Bugge and Wandel 1995; Coopers and Lybrand Deloitte 1992; Grunert and Kristensen 1995; Scan-Ad 1998). Price premiums for organic products in Great Britain, and more so in Denmark, are generally low compared to most other European countries ( $c f$. estimates in Hamm et al., 2002). As shown in Table 2, these premiums are often below 40\%. Thus, it would seem that the concentrated structure of Danish and British markets for organic foods serves to ensure effectiveness, sufficient supplies of homogenous quality and relatively low price premiums, thereby encouraging consumers to purchase organic products.

Looking at differences between user groups (data not shown) reveals interesting differences for Danish households. Heavy users exhibit the highest propensity to purchase organic through direct sales channels, doing $12 \%$ of their shopping in this way. In fact, $77 \%$ of organic goods sold directly are purchased by heavy users. Nevertheless, heavy users do most (57\%) of their shopping in supermarkets and 20\% in discount stores. Medium users and light users spend approximately two thirds of their organic budget in supermarkets and around one third in discount stores. Likewise, our survey results indicate that a considerable proportion (between one fourth and half depending on sales channel) of respondents state that their confidence becomes stronger when a food product is bought at a specialist store, farm gate, market stall or delivered directly from the producer - and this viewpoint is significantly more widespread among organic buyers. ${ }^{3,4}$ However, a considerable proportion (one fifth) state that this is the case when products are bought in a supermarket (significantly fewer among organic buyers). Consequently, our results indicate that consumer confidence does vary between sales channels, but that considerable heterogeneity in this variation is also observed between households. It appears that light users are generally confident of purchasing organic foods in supermarkets, while heavy users have more trust in direct sales channels. As such, two parallel markets, based on different types of sales channels and satisfying different consumer demands, have emerged.

\footnotetext{
${ }^{3}$ This is tested using a Likelihood Ratio test for independence in the cross tabulation of answers to the specific question by buyer/non-buyer status. The test compares the observed distribution with the expected distribution under the assumption that the answers are independent of buyer/non-buyer status. The degrees of freedom are: (number of possible answers - 1)*(number of possible states (2) -1) = number of possible answers - 1 . In all cases, significance is on at least the $5 \%$ level.

4 That is to say, households having an organic budget share $>2.5$. We have tested alternative buyer/non-buyer definitions, and in general, the observed differences do not change with changing definitions. Alternative definitions are related to other budget shares values (e.g. higher than 5\%), budget shares for specific products, stated willingness to pay, or households with the $10 \%$ or $25 \%$ highest budget shares (highest decile/quantile).
} 


\section{Perception and valuation of organic attributes}

Most studies show that health considerations play a major role in consumer preferences for organic foods. Other important attributes are environmental, animal welfare and quality attributes (CMA, 1996; von Alvensleben, 1998; Meier-Ploeger et al., 1996; Sylvander, 1995; Infood, 1997, 1998; Land, 1998; Scan-Ad, 1998; Coopers and Lybrand Deloitte, 1992; Byrne et al, 1994; Huang, 1996; Huang et al., 1990; Jolly, 1991). Storstad and Bjørkhaug (2003) suggest that the pioneers of organic consumption were primarily motivated by environmental concerns, but that as food safety concerns increase, the demand for organic foods increases faster.

In our Danish survey, we identify the valued attributes of organic goods to which consumers accord importance. Quite remarkably, most respondents state that improved animal welfare and environmental protection are the two most important features of organic production. Health attributes ${ }^{5}$ are rated as third most important, while taste and freshness are ranked as least important. Aggregating all organic attributes to either private good attributes (health, taste, freshness) or public good attributes (animal welfare, environmental attributes) yields some interesting results. Public good values are assigned approximately twice as much weight (importance) on the Likert scale as private good values. (For exact weights and standard deviations, see Wier et al., 2004). Approximately two thirds of total value can be assigned to public good values, leaving one third assigned to private good values. This result holds across product groups, as well as for organic goods in general. Public good values are widely attributed to organic goods, being acknowledged by $82 \%$ of all Danish households. Of these, $80 \%$ (66\% of all households) comprises households that acknowledge both private and public values, while households that only acknowledge private good-values constitute a negligible share (1\%). Finally, households that acknowledge no particular values for organic products whatsoever constitute $16 \%$ of all households.

Results from Brennan and Kuri (2002) suggest that a similar pattern can be observed in Great Britain. According to their survey, approximately two thirds of respondents believe that organic farming is better for the environment, while only $55 \%$ believe that organic food is healthier. Much fewer (20\% approximately) perceive the taste and appearance of organic foods as being better, although this latter pattern is significantly more pronounced among buyers as compared with non-buyers.

Before jumping to the conclusion that people primarily purchase organic foods by reason of their concern for the environment and animal welfare, we undertook some additional analyses. To find out what stated values entail for willingness to pay on the real market, we combined information on the stated values for organic goods (as revealed by our survey of Danish panel members) with actual purchasing

\footnotetext{
${ }^{5}$ Most respondents who perceive organic products as being healthier believe they are healthier because of the absence of pesticide and medicine residues. Other (minor) reasons are absence of synthetic additives, colouring agents and GMOs. Least emphasis is given to the possibility of organic products having fewer bacteria or having a higher vitamin and mineral content. Thus, the health attribute appears to be primarily related to the product being free from pesticide and medicine residues (and consequently expected to be healthier).
} 
behaviour (as revealed by purchase data from Danish panel members). We undertook a regression analysis, using each household's stated importance (5-point Likert scale) of the private and public good attributes of organic goods in order to explain the household's average organic budget share for all food types. More specifically, the model explains average weekly organic budget share for each household during 1997-2001, using stated values (private and public good values), a variable measuring health risk perception in relation to pesticide residues, and stated purchasing barriers as explanatory variables. These barriers were introduced to measure the importance of lack of interest and lack of trust, respectively. Some consumers, who assign values to organic product attributes, may at the same time be unresponsive or disinterested when it comes to actual shopping behaviour, either because they are not really dedicated or because they do not really trust organic goods. Finally, we control for the effects of household characteristics, such as income (approximated by total food expenditure), urbanisation, age of the oldest person in the household, presence and age of children, and educational level of the most highly educated person in the household.

The estimation results are shown in Table $4^{6}$, revealing the interesting fact that stated private good attributes do have a significant effect on the organic budget share, while the contribution from stated public good attributes is not significant. The effect from private good values is significant even when controlled for the influence of household characteristics, health risk concern and main stated purchasing barriers. We find that lack of trust in control, lack of interest in organic goods (i.e. feeling there are many other things to spend money on), stated lack of knowledge about organic goods, and lack of trust in any health effect from eating organic goods (due to the existence of many other risk factors in every day life), are all factors that significantly reduce organic shares. Health risk concern about eating foods that contain pesticide residues increases organic budget share significantly. Interestingly, re-doing the regression analysis for specific product groups (data not shown) reveals that these effects from stated values and concerns are similar across product groups. Some important exceptions to this pattern are observed, however. The acknowledgement of public good values does significantly increase the propensity to purchase organic cereals and bread. Moreover, for this single product group, concern about pesticide residues does not significantly influence the propensity to buy. Finally, in contrast to all other organic product groups, the propensity to purchase organic dairy goods does not increase significantly with increasing age.

Table 4. Regression results: model explaining Danish household organic budget share, 1997-2001 (1165 households)

\begin{tabular}{lcc}
\hline & \multicolumn{2}{c}{ All food types } \\
\cline { 2 - 3 } Intercept & Parameter & Standard deviation \\
\hline
\end{tabular}

${ }^{6}$ Almost identical results are found when using other modelling approaches such as Discrete Choice Modelling (Millock et al, 2004). The main results are also confirmed using a third modelling approach, taking full account of effects from differences in relative prices using a micro-econometric demand model to explain organic budget shares, in which each household's deviation from the average demand for organic foods is estimated as a household specific constant term (Hansen, 2005). These constant terms in principle capture all differences between household that are due to variations in socio-economic characteristics, attitudes and values and are ultimately explained by the variables shown in Table 4. 


\begin{tabular}{|c|c|c|}
\hline \multicolumn{3}{|l|}{ Stated values } \\
\hline -Stated private values & $1.07 * *$ & 0.11 \\
\hline -Stated public values & 0.08 & 0.11 \\
\hline \multicolumn{3}{|l|}{ Purchasing barriers } \\
\hline -No trust in control of Organic farming & $-0.89 * *$ & 0.17 \\
\hline -No interest in organic foods (many other things to spend money on) & $-0.68 * *$ & 0.19 \\
\hline -No trust in health effect from eating organic foods & $-0.91 * *$ & 0.18 \\
\hline -Not enough knowledge about organic foods & $-1.20 * *$ & 0.17 \\
\hline Pesticide/medicine residue health concern & $0.83^{* *}$ & 0.15 \\
\hline \multicolumn{3}{|l|}{ Regions (western rural area is base) } \\
\hline -Capital area & $1.87 * *$ & 0.36 \\
\hline -East Denmark (except from capital area) & 0.57 & 0.34 \\
\hline -Western towns and uplands & $1.36 * *$ & 0.34 \\
\hline \multicolumn{3}{|l|}{ Education length (lowest level is base) } \\
\hline -Short & $0.81^{* *}$ & 0.29 \\
\hline -Medium & $1.95^{* *}$ & 0.30 \\
\hline -Long & $1.72 * *$ & 0.48 \\
\hline Age of oldest person in household (categories) & $0.25 *$ & 0.10 \\
\hline \multicolumn{3}{|l|}{ Presence of children } \\
\hline -Children between 0-14 Years & $0.94 * *$ & 0.32 \\
\hline -Children between 15-20 Years & $-0.82 *$ & 0.34 \\
\hline \multirow[t]{2}{*}{ Log (Total weekly food expenditure per consumption unit) } & & 0.27 \\
\hline & $0.92 * *$ & \\
\hline
\end{tabular}

Notes:

* Significant at $5 \%$ level

** Significant at $1 \%$ level

Source: Own estimates based on questionnaire and GfK purchase data set, 1997-2001.

Unfortunately, we cannot undertake a similar analysis for British households Since information on stated values is not available at the household level, we are unable to combine the available data with purchasing behaviour at the household level. However, information (provided by TNS) about the Top-20 statements most frequently strongly agreed with by organic buyers in the TNS household panel (cf. Appendix B), compared to the average household shopper in the same panel, suggests that British organic buyers probably do share some of the same values as Danish organic buyers. Thus, the statements most over-indexed (16\% more frequently agreed with among organic buyers as compared to the average shopper) concern organic foods tasting better and having better texture - both relating to private good attributes. Statements on public values, such as organic foods having animal welfare and environmental attributes are also over-indexed among buyers, although to a lesser extent (12\% over-indexed). Interestingly, the health related statement "organic foods are safer for children" is the least over-indexed (9\%), suggesting that health concerns may be less prevalent among British organic buyers than Danish buyers - and moreover, that households with children are underrepresented among British organic buyers, as confirmed in next Section on sociodemographic factors. However, since we have no information about standard deviations for these index estimates, it is not possible to test the significance of differences between organic buyers and non-buyers for British households. 
Consequently, for Danish households (and possibly for British households), we can conclude that even though households more often assign value to (and additionally assign highest values to) public good attributes, their actual propensity to purchase these goods is in fact strongly related to the extent to which they value private good attributes. Fewer consumers acknowledge private good attributes (compared to public), but those who do, exhibit the highest propensity to purchase organic foods. It is worth emphasising, however, that the public good attributes of organic products are in fact widely acknowledged and valued. Consequently, assigning value to public good attributes may constitute a necessary (but not a sufficient) condition for considering the purchase of organic products. However, assigning value to private good attributes appears to constitute both necessary and sufficient conditions, determining the extent to which these products are actually purchased. .

\section{Socio-demographic factors}

Earlier research has identified a number of socio-economic and demographic variables that significantly influence demand or willingness to pay for organic goods. However, almost all of these studies are based upon stated rather than observed behaviour. In this section we examine the extent to which these findings are supported by our data concerning Danish and British observed behaviour.

Several studies (Bjerke 1992; Grunert and Kristensen 1995; Infood 1997a, 1998a; Buzby and Skees 1994; Byrne et al. 1991; Ott, 1990; Huang, 1996; Haest, 1990; Jolly, 1991; Menghi 1997; The Packer, 1998) have found that younger consumers (under 45 years old) have a higher propensity to purchase organic products than older consumers. However, other studies have found (Bugge and Wandel 1995; Fricke 1996; Fricke and von Alvensleben, 1997; Meier-Ploeger et al. 1996) that older consumers also have a high propensity to buy organic products. Misra et al. (1991a) found no significant correlation between age and buying propensity. A review of the literature on this issue points out that there may be a pattern whereby younger consumers are over-represented among early adopters in developing markets, while older consumers appear to be well represented in more mature markets (O’Doherty Jensen et al. 2001).

One study (Infood, 1998) found that buying propensity increases with increasing level of urbanisation, while Jolly (1991) found the opposite relationship. Finally, no correlation was found by Jörgensen (2001) and Huang et al. (1990, 1993).

According to Menghi (1997), Grunert and Kristensen (1995), Jörgensen (2001), Ott (1990), and Thompson and Kidwell (1998), the propensity to buy organic foods is positively correlated to household size. In contrast, Jolly (1991), Ott (1990), Huang (1996), Goldman and Clancy (1991), Byrne et al. (1991, 1994), Grunert and Kristensen (1995), Bjerke (1992), and Swanson and Lewis (1993), found that household size had no significant influence. Thompson and Kidwell (1998) and Land (1998) found that the presence of children in the household increased the probability of choosing organic products. In contrast, Beckmann 
(2001), Jolly (1991), Buzby and Skees (1994) and Packer (1998) found that the presence of children does not affect the purchases of organic products significantly.

Haest (1990), Buzby and Skees (1994), Grunert and Kristensen (1995), and Beckmann (2001) found that household income has no significant influence on demand/willingness to pay for organic/freefrom-pesticides goods. Menghi (1997), Misra et al. (1991), Fricke (1996), Jörgensen (2001) and MeierPloeger et al. (1996) found, however, that households with middle and higher income levels show a greater tendency to purchase organic foods. Results from Bugge and Wandel (1995), Menghi (1997), Ott (1990), Huang (1996), Misra et al., (1991), Byrne et al. (1991) and Haest (1990) indicate that a higher level of education is positively correlated with the tendency to buy/pay more for organic products or products produced without pesticides. This was not supported, however, by the findings of Beckmann (2001), Buzby and Skees (1994) or Thompson and Kidwell (1998), and only partly by Byrne et al. (1991).

Our regression analysis on Danish household data (Table 4) reveal that higher disposable household income (approximated by total food expenditure), older age-group and higher educational level all significantly increase organic budget share, as does the presence of children younger than 15 years. Very remarkably, the presence of children aged 15 to 20 years, who are living at home, has the opposite effect, tending to reduce organic shares. This difference may indicate that health concerns are particularly prevalent among parents of young children. We find that urbanisation also influences organic shares significantly. Household organic shares are higher in urban areas, especially so in areas adjacent to the capital city, while the lowest shares are observed in western rural areas.

For British households, a similar pattern is observed for most of these socio-demographic characteristics, as apparent from Table 5. Households in the metropolitan area (London) hold significantly higher organic budget shares, the highest in the whole of Britain. Significantly higher shares are furthermore observed in the southern regions of England, as well as Wales, while households in the regions of Northern England and Scotland display the lowest propensity to purchase organic products. At this level of regional aggregation, however, it is not possible to establish an explicit measure of the importance of urbanisation.

Social group is employed as an indicator of educational levels and income brackets. Table 5 reveals that the propensity to purchase organic tends to increase in accordance with higher social status. However, the highest organic budget shares are observed for middle class households, shares in the upper middle class being in fact lower. Quite interestingly, a similar pattern is observed in Denmark. Table 4 reveals that medium and long education increases the propensity to purchase organic foods, a pattern that is more pronounced among those with a medium level of education. Likewise, when re-doing the regression analysis of Danish data, employing social groups that correspond to British social groups (see Appendix C), we find a higher propensity to purchase among middle class and upper middle class households. 
Table 5. Regression results: model explaining British household organic budget share, 2001-2003 (20,334 households)

\begin{tabular}{|c|c|c|c|}
\hline Intercept & & $\begin{array}{l}\text { Parameter } \\
0.92 * *\end{array}$ & $\begin{array}{l}\text { Std. Dev. } \\
0.14\end{array}$ \\
\hline \multirow[t]{9}{*}{ Region (Yorkshire is base) } & East England & $0.52 * *$ & 0.13 \\
\hline & Lancashire & 0.07 & 0.11 \\
\hline & London & $1.80 * *$ & 0.10 \\
\hline & Midlands & $0.56^{* *}$ & 0.10 \\
\hline & North East England & -0.20 & 0.14 \\
\hline & South West England & $0.50 * *$ & 0.17 \\
\hline & Scotland & -0.04 & 0.12 \\
\hline & South England & $0.67 * *$ & 0.12 \\
\hline & Wales+West England & $0.55 * *$ & 0.12 \\
\hline \multirow[t]{5}{*}{ Social group (Working class is base) } & People on benefit & $0.37 * *$ & 0.10 \\
\hline & Skilled working class & $0.28 * *$ & 0.09 \\
\hline & Lower middle class & $0.92 * *$ & 0.08 \\
\hline & Middle class & $1.82 * *$ & 0.11 \\
\hline & Upper middle class & $0.98 * *$ & 0.38 \\
\hline \multirow{4}{*}{$\begin{array}{l}\text { Presence of children ( } 0 \text { children is } \\
\text { base) }\end{array}$} & 4 or more children & $-1.13^{* *}$ & 0.23 \\
\hline & 3 children & $-0.45 * *$ & 0.14 \\
\hline & 2 children & $-0.65 * *$ & 0.09 \\
\hline & 1 child & $-0.26 * *$ & 0.08 \\
\hline \multirow[t]{3}{*}{ Number of adults ( 1 adult is base) } & 2 adults & $-0.23 * *$ & 0.07 \\
\hline & 3 adults & $-0.69 * *$ & 0.10 \\
\hline & 4 or more adults & $-1.20 * *$ & 0.12 \\
\hline \multirow{5}{*}{$\begin{array}{l}\text { Age of key household shopper } \\
\text { (less than } 30 \text { years is base) }\end{array}$} & 30-39 years & $0.56 * *$ & 0.09 \\
\hline & 40-49 years & $0.69 * *$ & 0.10 \\
\hline & 50-59 years & $0.54 * *$ & 0.10 \\
\hline & 60-69 years & $0.27 *$ & 0.11 \\
\hline & 70 years and more & 0.05 & 0.12 \\
\hline
\end{tabular}

We find that the presence of children is important, tending to lower the organic budget share significantly. For each additional child in the household, the propensity to purchase organic foods decreases. Very interestingly, re-doing the regression analysis on Danish data with the presence of children as one variable (aggregated across age brackets) reveals that the presence of children (regardless of age) in the household does not significantly influence organic budget shares in Denmark. Furthermore, when breaking down the 'presence of children' variable by the number of children instead of age brackets (as shown in Appendix C), we find that the presence of one or two children increases buying propensity, while the presence of three or more children decreases it. Neither of these tendencies, however, are identified at a significant level. However, we previously found (as shown in Table 4) that the presence of younger children does increase the propensity to purchase organic, while presence of older children has the opposite effect. 
We conclude therefore on this point that the propensity to purchase organic is not significantly related to the presence of children per se, but rather to the presence of younger children. One possible explanation of this pattern may be related to the fact that food expenditure in larger households with older children constitutes a relatively heavier economic burden, leaving less extra money for organic goods. Parents may be more concerned about health and food safety problems in relation to babies and young children, while an increasing cost-of-living/family size effect tends to dominate when children reach adolescence. It is possible that a similar pattern could be observed for British households, but data restrictions do not allow this analysis to be undertaken. Unfortunately, we have no information about the ages of children among households in the British panel.

It is clear, however, that an increasing number of adults in British households lowers the organic budget share. Thus, propensity to purchase organic generally decreases with household size, disregarding whether additional members are children or adults. A similar pattern is observed in Denmark (see Appendix C), where the number of adults in the household is negatively correlated with organic household budget share. Again, it would seem that this pattern is related to the relatively heavier economic burden imposed by food expenditure in larger households, indicating in turn the importance of price premiums in the purchasing decisions made by household shoppers.

Age significantly influences the organic budget share of British households, with middle-aged households having the highest propensity to purchase organic, while the lowest propensity is found in the youngest age group and among the elderly. The pattern in Denmark is somewhat different, where the propensity to purchase organic foods generally increases with age, although a local peak for the age group 40-49 years also appears here. This becomes clear when the regression analysis for Danish households is redone (shown in Appendix C) using age intervals for key household shoppers corresponding to the British model.

Further regression analyses of British households' purchase of specific product groups (data not shown) reveals that effects from stated values and concerns are relatively similar across product groups. This was also the case for Danish households. Some interesting exceptions are apparent for British households however. Organic fruit, milk and eggs are primarily purchased by younger consumers, organic yoghurt by older consumers, while organic vegetables are purchased by households in all age groups. Households in Wales, western and south-western regions of England generally display a relatively high propensity to purchase organic products, but a closer look at product groups reveals that this does not hold true for organic eggs and vegetables - most probably because farm gate sales and home production are prevalent in these areas. Organic eggs, milk and yoghurt are primarily purchased by middle class households, and in particular by the upper middle class. In contrast, organic fruit and vegetables are primarily purchased by middle class and lower middle class households.

\section{Information and labelling}


There appear to be two ways in which producers can seek to increase the trustworthiness of products (and consumers can ensure authenticity). The first is by means of direct personal contact between the consumer and the producer/seller, which is achieved when foods are purchased at farm gates, market stalls or in specialist stores. Direct personal contact makes it possible for the consumer to achieve detailed information about products, production methods or specific producers. The second way is by means of labelling or other standardised information provision about attributes on product packaging (Torjusen et al. 2004). For organic goods sold in supermarkets, which are most often supplied by large-scale industrial food production units, standardised information is the only means by which consumers can identify authenticity. For this type of organic market, familiar, easily identifiable and trustworthy labelling is a necessary precondition for developing and maintaining high market shares for organic products.

Our survey results confirm that the national Danish organic label is trusted and well known, and in general people also have a good understanding of the rules governing organic farming (cf. Wier et al., 2005). The situation in Britain is somewhat different in regard to labelling. There are a total of five approved national inspection bodies, each of which has its own label. Among these, the logo of the Soil Association is the most widely recognized (Hamm et al. 2002). It is also the most widespread, since that body certifies more than 70\% of organic products in Britain (British House of Commons, 2001). Thus, even though the labelling situation is not as simple, clear or unambiguous as in Denmark, the multiplicity of organic labels and certification bodies has not constituted a problem in the past (according to British House of Commons, 2001). It may do so, however, as the organic market develops further. Developments towards an even more dominant role for the Soil Association logo or further cooperation between certifying bodies, leading to a merging of competing labels, would probably benefit this market.

Labelling is the means by which consumers distinguish organic from conventional products in mainstream markets, and it is clearly functioning effectively at present in both the British and Danish markets. However, our survey results indicate that consumers desire information on a wide range of points regarding product attributes, producers and production methods. For Danish households, three out of four respondents state that their confidence in the quality of food products becomes stronger when there is information on the packing about where and how the product is produced. A well-known brand also appears to be highly important in ensuring confidence: $54 \%$ of all respondents trust branded products more. Both of these patterns are distinctly more pronounced among medium and heavy users of organic products as compared to others. Apart from basic food attributes such as freshness and taste, most importance is attributed to (conventional and organic) products being free from medicine residues, pesticide residues and additives. Less highly ranked are: low fat content, animal welfare and environmental considerations, as well as origin of products. Nutritional value (vitamins and minerals), brand, ease of preparation, being delivered from specific farms, markets or processors, and being organic follow (in that order of priority). By and large, the same ranking of attributes is found in Weatherell et al. (2003), indicating similarities between British and 
Danish consumers on these points. It is clear that the information needs of consumers in regard to several of these points are not met by standard information currently provided in mainstream sales channels.

\section{Closeness and traceability}

Two out of three Danish households state that it is important to them that the goods they purchase are produced in Denmark. One out of three stare that this is very important, and significantly more among organic buyers than non-buyers. The origin attribute is closely related to trust, with $80 \%$ of the households stating that their confidence in the quality of food products is greater when the producer is domestic - and again significantly more among organic buyers. Among all respondents, $72 \%$ would prefer to buy conventional domestic fruit and vegetables than organic foreign fruit and vegetables. Thus, the origin attribute commonly overrules organic attributes, although this order of priority is found to a greater extent among non-buyers. This preference is particularly interesting in the light of the fact that the British and Danish organic markets rely heavily on imported goods to satisfy market demand. Thus, in both countries, most organic fruit and vegetables are imported, and so is a large percentage of organic cereals. Organic dairy products and meat are mostly of national origin, but again, a large percentage of organic fodder in livestock production is imported. Apparently, however, this has not influenced demand negatively up to the present. This may be partly due to the fact that when imported foods are packed or processed on the domestic market, they tend to be perceived as domestic products. It may be also partly explained by trust in foreign organic products becoming enhanced by national labelling, as suggested by our survey results (see Wier et al. 2005). It does indicate, however, that demand could be negatively influenced in the future by the provision of more adequate consumer information on this issue.

Convenience or ease of preparation is an important issue in food choice. Several studies (e.g. Steenkamp, 1997; Gofton and Ness, 1991) emphasise two major trends in today's consumption patterns: the need for convenience food and an increasing consciousness of the need for healthier eating habits. Modern highly processed convenience foods and ready-made meals may not be perceived, however, as being compatible with the ideals of being health conscious and having a preference for organic foods. Organic farming has been associated with concepts such as freshness, nutritional value, simple and healthy meals made from raw ingredients, traceability, local supply, direct relationships between farmers and consumers and, not least, the avoidance of synthetic additives and preservatives.

However, a large number of highly processed organic products, including convenience products, are already available on Danish and British markets. Britain has the widest range of organic foods in the world today, offering more than 1200 items in the organic food range. Most European retailers are far behind this level, and only Denmark comes close with more than 800 items in the organic food range (Organic Monitor, 2002). The trend towards convenience is observed throughout Europe, however, and organic convenience foods have been identified as the organic product type expected to have the highest growth rate in the years to come (Padel et al., 2003). 
The Danish survey data throw some light on trust in organic convenience foods. Firstly, as we have seen, the attribute 'ease of preparation' tends to be ranked by Danish households as being more important than the attribute of 'being organic' as such. The convenience attribute thus appears to overrule the organic attribute. We also find with respect to processed products, however, that stated consumer confidence in adherence to organic rules is considerably weaker (cf. Wier et al., 2004). When asked about specific kinds of organic convenience products, consumer confidence appears to vary considerably between product groups. Up to one fourth of all respondents (depending on the product at issue) state that they are willing to pay more for organic convenience products. It is furthermore noteworthy that organic buyers are significantly more willing to pay a price premium for organic convenience products - even though they usually have a lower (stated) demand for convenience products. Moreover, organic buyers generally have a higher level of confidence in organic convenience products. Thus, even though a large number of consumers are reluctant to purchase organic convenience foods, a considerable proportion would in fact be willing to purchase organic convenience products. Those who are already organic buyers are significantly overrepresented in the latter group and, according to their own statements, are not reluctant to trust organic convenience products.

\section{Conclusions and perspectives}

The Danish organic food market is characterised by very high organic market shares and the British organic food market is rapidly growing. Our purchase data reveal that this holds especially for organic dairy products and vegetables (in that order) in both countries. On average, heavy users purchase more than half of all organic products in both countries, but considerable variation in demand levels is also observed between product groups. Surprisingly, neither Danish nor British households exhibit stable organic budget shares throughout the observation periods at issue. Generally speaking, most households have increased their propensity to buy organic foods during the period, but considerable numbers of households have also moved in the opposite direction. These results suggest that, in practice, many factors exert influence on food choices made in shopping contexts, and that surveys of buyer motives that exclusively rely upon the measurement of declared values, concerns and intentions may have less predictive value with respect to demand level than previously thought.

The Danish and British organic markets are both industrialised and concentrated organic food markets, based on a high proportion of imported, in some cases highly processed, foods and large-scale units of production, processing and distribution. These market characteristics may influence consumer confidence in organic products in the longer term insofar as these traits are perceived as being incompatible with organic principles. This incompatibility is only partly factual, however. Our results suggest that for most light users, and to some extent medium users, the current market structure does not constitute a problem at present. Thus, demand for organic foods in Great Britain and Denmark appears to be primarily sustained by private good attributes such as food safety and quality concerns. Public good attributes (environmental and animal 
welfare attributes) are more widely acknowledged with respect to organic products, but appear to exert less influence on the actual propensity to purchase organic goods than do private good attributes. In this light it can be seen that supermarkets, as compared to other sales channels, have the advantage of being able to ensure high turnover and homogenous quality, thus guaranteeing freshness, taste and appearance qualities. Furthermore, certified organic foods carry some guarantee with respect to the absence of residues and a wide range of food additives, disregarding the sales channel involved. These factors entail that supermarkets and discount stores are able to offer easy access to stable supplies of a large variety of organic foods with all of the characteristics that are important to most consumers. Moreover, they can do so at a substantially lower price premium compared to other sales channels. Thus, given that the organic labels remains trusted, demands from most light and medium users can be largely satisfied.

For heavy users, however, the situation is different, as the industrialised and concentrated market structure may tend to undermine confidence. Our results indicate that a more general failure to make detailed information about products, suppliers and processing methods available to consumers is particularly likely to undermine confidence in organic products in this group and that lack of information currently constitutes a source of consumer dissatisfaction. Issues such as traceability, production methods, food miles, local, regional or national origin and the character of the sales channels as such refer to concerns that are strongly held by the group of heavy users, who account for half of the total demand. For that reason, a parallel, non-standardised market based on direct sales has emerged in both countries. Thus, heavy users account for more than three-quarters of all sales of organic products through alternative and direct sales channels, a pattern that suggests some level of dissatisfaction with mainstream sales channels.

We do not at present know enough about the reasons why households reduce their organic budget share. Viewed from the standpoint of the demand structure as examined here, it can be concluded that mainstream sales channels constitute at present a relatively robust means of encouraging more consumers to become light or medium users of organic food products. If, however, heavy users of organic foods are to increase their organic budget share and their loyalty to mainstream sales channels, it would seem that more attention should be given to the provision of consumer information and to the development of regional policies for increasing local supplies to supermarkets, including supplies from small producers and processors.

\section{References}

Andersen, L.M. (2001): Documentation of household panel data, Working paper no.1, available at www.akf.dk/organicfoods.

Andersen, L. M. (2002): Consumer evaluation of environmental and animal welfare labelling: An econometric analysis on panel data using mixed multinomial logit. Working paper no.6, available at www.akf.dk/organicfoods. 
Armand-Balmat, C. (2002): Comportement du consommateur et produits biologiques: le consentement á payer pour la caractéristique biologique. Revue d'économie politique, 112:33-46.

Baadsgaard, A., K.G. Grunert, S.C. Grunert \& H. Skytte (1994), Undersøgelse af mulighederne for eksport af økologiske mcelkeprodukter til Nordtyskland. Aarhus School of Business, Aarhus

Beckmann, S. C. (2001): Danske forbrugere og økologiske fødevarer, Copenhagen Business School, Copenhagen.

Beharrell, B. and J.H. MacFie (1991), “Consumer Attitudes to Organic Foods”, British Food Journal, Vol.93, No.2, pp.25-30.

Bjerke, F. (1992), Forbrugernes interesse for økologiske produkter, Roskilde University, Roskilde.

Brennan, C. S and V. Kuri (2002): Relationship between sensory attributes, hidden attributes and price in influencing consumer perception of organic foods. Paper presented af the COR conference, March, 2002, Aberystwyth.

British House of Commons (2001): Report on organic farming. British House of Commons, January $26^{\text {th }} 2001$. Available at www.organic-europe.net.

Briz, T and M. Al-Hajj (2003): Consumer's Attitude versus Organic Products. $83^{\text {rd }}$ EAAE seminar, Chania, Crete, September 2003.

Brombacher, J. (1992): Ökonomische Analyse des Einkaufsverhaltens bei einer Ernährung mit Produkten des Økologischen Landbaus (in German). Institut für Agrarpolitik, Universität Hohenheim. Landwirtschaftverlag, Stuttgart.

Brunsoe, K. (1996), Fødevarerelateret livsstil - udvikling af et måleinstrument til markedsovervågning af forbrugere for fødevareindustrien. PhD dissertation, MAPP center, Aarhus School of Business, Aarhus

Brunsoe, K. \& L. Bredahl (1997), ”Fødevarerelaterede livsstile i forskellige europæiske kulturer”, Dansk Sociologi, Vol. 8 No.4, pp.23-35.

Bugge, A. and M. Wandel (1995), ”Forbrukerholdninger til moderne matvareproduksjon”, Landbruksøkonomisk Forum, Vol.12, No.1, pp.15-25.

Buzby, J.C. and J. Skees (1994), Consumers Want Reduced Exposure to Pesticides on Food, Food Review, Vol.17, No.2, pp.19-22.

Byrne, P.J., U.C. Toensmeyer, C.L. German and H.R.Muller (1991), Analysis of Consumer Attitudes Toward Organic Produce and Purchase Likelihood, Journal of Food Distribution Research, Vol. 22, June, pp.49-62.

Byrne, P.J., J.R. Bacon and U.C. Toensmeyer (1994), “Pesticide Residue Concerns and Shopping Location Likelihood”, Agribusiness, Vol.10, No.6, pp.491-501.

Carson, R., N.E. Flores, K.M. Martin and J.L. Wright (1996), "Contingent Valuation and Revealed Preference Methodologies: Comparing the Estimates for Quasi-Public Goods", Land Economics, 72: 80-99.

CMA (1996), „Einstellungen und Marktschätzungen aus Verbrauchersicht zu “alternativen Nahrungsmitteln/Biokost/Ökoprodukten” insbesondere zu Obst und Gemüse“. MAFO Memo No 621, Centrale Marketing-Gesellschaft der deutschen Agrarwirtschaft, Bonn.

Cook, R. (1991), “Consumer Demand for Food Safety-Oriented Marketing Labels: Implications for Sustainable Agriculture”, Paper presented at the International Agricultural Economics Association Meeting, Tokyo, Japan, August 1991.

Coopers and Lybrand Deloitte (1992), Going Organic - The Future for Organic Food and Drink Products in the UK, Birmingham, UK. 
Cummings, R. G. Harrison and E. Rutstrom (1995), "Home-grown values and hypothetical surveys: Is the dichotomous choice approach incentive compatible", American Economic Review 85, 260-266

Danish Foreign Ministry (1998a), Salg af økologiske fødevarer i Tyskland (Sales of organic Foods in Germany). Royal Danish Embassy in Bonn.

Danish Foreign Ministry (1998b) Marked for økologiske fødevarer i Storbritannien (Market Potential for Organic Foods in Great Britain). Royal Danish Embassy in London.

Danish Foreign Ministry (1996), Salg til den tyske detailhandel med fokus på levnedsmidler (Food Sale to German Retail Trade), Royal Danish Embassy in Bonn.

Drake, L. and H.Holm (1989), Konsumenternes attityder till alternativt producerat kött - preliminär redovisning av intervju och enkätstudie, Institute of Economics, Uppsala.

Fricke, A. (1996), „Das Käuferverhalten bei Öko-Produkten. Eine Längsschnittanalyse unter besonderer Berücksichtigung des Kohortenkonzepts“. Europäische Hochschulschriften, Reihe V, Volks- und Betriebswirtschaft, Bd. 1960. Peter Lang: Frankfurt.

Fricke, A. \& R. von Alvensleben (1997), “Consumer Attitudes towards Organic Food and an Application of Cohort Analysis - 1984 - 1989 - 1994”. Working Paper No. 1, Lehrstuhl für Agrarmarketing, Christian-Albrechts University, Kiel.

Frykblom, P. (1997), "Hypothetical question modes and real willingness to pay", Journal of Environmental Economics and Management 34, 275-287.

GfK Danmark (1996), Den Danske Gris - Forbrugerholdninger til svineproduktion og svinekød, Danske Slagterier og GfK Danmark A/S, København.

Giraud, G (2003): Consumer perception and marketing of origin and organic labelled food products in Europe. $83^{\text {rd }}$ EAAE seminar, Chania, Crete, September 2003.

Glaser, L.K. and G.D. Thompson (1998): Demand for Organic and Conventional Frozen Vegetables. Paper presented at the American Agricultural Economics Association Annual Meeting, August 8-11, Nashville, Tennessee.

Glaser, L.K. and G.D. Thompson (2000): Demand for Organic and Conventional Beverage Milk. Paper presented at the Western Agricultural Economics Association Annual Meeting, June 29-July 1, Vancouver, British Columbia.

Gofton, L. \& M. Ness (1991), “Twin Trends: Health and Convenience on Food Change or Who Killed the Lazy Housewife?”, British Food Journal, Vol.93, No.7, pp.17-23.

Goldman, B.J. and K.L. Clancy (1991), “A Survey of Organic Produce Purchases and Related Attitudes of Food Cooperative Shoppers”, American Journal of Alternative Agriculture, Vol.6, No.2, pp.89-95.

Grunert, S. and K. Kristensen (1995), Den danske forbruger og økologiske fødevarer, Odense University.

Hack, M.D. (1995), “Organically Grown Products: Perception, Preferences and Motives of Dutch Consumers”, Acta Horticulturae, Vol. 340 Jan., pp. 247-253.

Haest, C. (1990), “From Farmer to Shelf: Trade of Organically Grown Products”, Ecology and Farming, Vol.1 No.1, pp. 9-11.

Hamm, U. and J.Michelsen (1996), “Organic Agriculture in a Market Economy. Perspectives from Germany and Denmark”, in Østergaard, T. (ed.), Fundamentals of Organic Agriculture - Proceedings from the $11^{\text {th }}$ IFOAM International Scientific Conference, August 11-15, 1996, Copenhagen. 
Hamm, U., F. Gronefeld, D. Halpin, N. Kristensen, T. Nielsen, M. Bruselius-Jensen, P. Scheperlen-Bøgh, M. Beckie, C. Foster, P. Midmore, and S. Padel (2002): The organic food market and marketing initiatives in Europe: a preliminary analysis, Institute of Rural Studies, University of Wales, UK.

Hansen, L.G. (2005): Organic crowding out? - A study of Danish organic food demand (in press). SOEM Memo, AKF: Copenhagen.

Hansen, J.K. and H. C. Sorensen (1993), The Importance of Price for the Sale of Ecological Products. MAPP working paper no.13, Aarhus School of Business, Aarhus.

Huang, C.L. (1993), “Simultaneous-Equation Model for Estimation Consumer Risk Perceptions, Attitudes and Willingness-to-pay for Residue-Free Produce”, Journal of Consumer Affairs, 27:377-396.

Huang, C.L. (1996), “Consumer Preferences and Attitudes Towards Organically Grown Produce”, European Review of Agricultural Economics, Vol.23 No. 3-4, pp.331-342.Huang, C.L, S. Misra \& S.L. Ott (1990), “Modeling Consumer Risk Perception and Choice Behavior: The Case of Chemical Residues in Fresh Produce”, in Mayer, R.N (ed.), Enhancing Consumer Choice, Proceedings of the Second International Conference on Reseach in the Consumer Interest, Snowbird, Utah, USA, August, 1990, American Council on Consumer Interests, Columbia, Missouri, USA.

Infood (1997a), Forbrugernotat, http://www.ecoweb/infood/

Infood (1997b), Kvalitativ analyse af forbrugernes holdninger, http://www.ecoweb/ infood/

Infood (1998), Kvalitativ analyse af forbrugernes holdninger til økologiske fødevarer, http://www.ecoweb/infood/ Irish, N.A. \& C.P. Ries (1987), “Nutrition Information Needs and Concerns of Food Cooperative Members”, Journal of Nutrition Education, Vol.19, No.1, pp.11-15.

Jolly, D.A. (1991), “Differences between Buyers and Nonbuyers of Organic Produce and Willingsness to Pay Organic Price Premiums”, Journal of Agribusiness, Vol.9 No.1, pp. 97-111.

Jörgensen, C., (2001), “Prisbildning och Efterfrågan på Ekologiska Livsmedel (in Swedish). Livsmedelekonomiska Instituttet, SLI, Report No. 2001:1, Lund.

Kafka, C. and R. von Alvensleben (1998), Consumer Perceptions of Food-Related Hazards and the Problem of Risk Communication, http://www.uni-kiel.de:8080/Agraroekonomie/Abteilungen/agrarmarketing

Kinsey, J. \& B. Senauer (1996), “Consumer Trends and Changing Food Retailing Formats”, American Journal of Agricultural Economics, Vol.78 No, 5, pp.1187-1191.

Kramer, C. (1986), “Food Safety: Consumer Preferences, Policy Options, Research Needs”, in Clancy, K (ed.), Consumer Demands in the Marketplace, Proceedings of a workshop held in Airlie, Virginia, Oct.27-29, 1986, Resources for the Future, Washington, D.C.

Kramer, C. (1990), “Food safety: The Consumer Side of the Environmental Issue”, Southern Journal of Agricultural Economics, Vol. 22 No 1, pp. 33-40.

Krämer, A., B. Harting \& S. Stadtfeld (1998), Siegeszug der “Bio-Lebensmittel” im Handel?, http://www.agp.unibonn.de/mafo/staff/oeko3a.htm.

Land, B (1998), “Consumers` Dietary Patterns and Desires for Change”, MAPP Working paper, No.31, Roskilde University, Roskilde.

Lee, K. (1989), “Food Neophobia: Major Causes and Treatments”, Food Technology, 43 No.12, pp.62-73.

Meier-Ploeger, A., W. Merkle, I. Mey and F. Wörner (1996), Stärkung des Verbrauchs ökologischer Lebensmittel. Hessisches Ministerium des Innern und für Landwirtschaft, Forsten und Naturschutz, Wiesbaden. 
Melton, B., W.Huffman, J. Shogren and J. Fox (1996), “Consumer Preferences for Fresh Food Items with Multiple Quality Attributes: Evidence from an Experimental Auction of Pork Chops”, American Journal of Agricultural Economics, Vol.78 No.4, pp.916-923.

Menghi, A. (1997), Consumer Response to Ecological Milk in Sweden, Swedish Agricultural University, Uppsala.

Michelsen, J. U. Hamm, E. Wynen and E. Roth (1999), The European Market for Organic Products: Growth and Development. Hohenheim University, Stuttgart.

Millock, K, M. Wier and L. M. Andersen (2004): Consumer Values and Willingness to Pay for Organic Foods. 13th annual EAERE Conference, Budapest, June 2004.

Misra, S., C.L.Huang and S.L.Ott: (1991), “Consumer Willingness to Pay for Pesticide-Free Fresh Produce”, Western Journal of Agricultural Economics, Vol.16, No.2, pp.218-227.

Mitchell, V. W. (1998): A role for consumer risk perceptions in grocery retailing.British Food Journal, 171 (4).

Morgan, K. and J. Murdoch (2000): Organic vs. conventional agriculture: Knowledge, power and innovation in the food chain. Geoforum 31: 159-173.

O’Doherty Jensen, K. et al., (2001): Økologiske Fødevarer og Mennskets Sundhed [Organic Foods and Human Health]. Foulum: Danish Research Centre for Organic Farming, Report nr. 14.Organic Monitor (2002): British consumers spoilt for choice in organic market. Organic monitor, January, 2002, available at www.organicmonitor.com

Ott, S.L. (1990), “Supermarkets Shoppers’ Pesticide Concerns and Willingness to Purchase Certified Pesticide Residue-Free Fresh Produce”, Agribusiness, Vol.6, No.6, pp.593-602.

The Packer (1998), Fresh Trends - A 1998 Profile of the Fresh Produce Consumer, Overland Park KS:Vance Publishing.

Padel, S. C. Seymour, and C. Foster (2003: SWP 5.1. Report of all three rounds of the Delphi inquiry on the European market for organic food. October, 2003, OMIaRD.

Pinton, R. (1998), Italien Organics. Draft, Studio Bio. E-mail: studio.bio@aiab.it

Produce Studies (1998), The European Organic Food Market. Final Report. The United States Department of Agriculture, The Hague.

Redman, B.J. (1980), “The Impact of Women’s Time Allocation on Expenditure for Meals Away from Home and Prepared Foods”, American Journal of Agricultural Economics, Vol. 22 No.2, pp.234-237.

Richter, T, O. Schmid, B. Freyer, D. Halpin, R. Vetter (2000) Organic consumers in supermarkets, new consumer group with different buying behaviour and demand, in Alföldi, T, W. Lockeretz and U. Niggli (eds): Proceedings from the $13^{\text {th }}$ International IFOAM conference, Zürich, pp. 542-545.

Scan-Ad (1998), Grøn Analyse, Del 1 and 2, Scan-Ad, Odense.

Setrab (1998), Organic Farming. http://www.setrabio.com/setrab.

Steenkamp, J-B.E.M. (1997), “Dynamics in Consumer Behavior with Respect to Agricultural and Food Products” in Wierenga, B et al. (eds.), Agricultural Marketing and Consumer Behavior in a Changing World, Kluwer Academic Publishers, Boston/London/Dordrect.

Storstad, O. and H. Bjørkhaug (2003): Foundations of production and consumption of organic foods in Norway: Common attitudes among farmers and consumers? Agriculture and Human Values, 20:151-163.

Swanson, R.B. and C.E. Lewis (1993), “Alaskan Direct-Market Consumers: Perception of Organic Produce”, in Home Economics Research Journal, Vol. 22, 138-155. 
Sylvander, B. (1995), "Conventions on Quality in the Fruit and Vegetables Sector: Results on the Organic Sector", Acta Horticulture, Vol. 340, Jan., pp.241-246.

Sylvander, B. (1996), The French Organic Market International Organic Market Study. Biofair: Camara de comercio de Costa Rica.

Synergie (2002): The specialized trade for organic products in Europe. Available at www.synergie-online.com.

Thompson, G.D. (1998), “Consumer Demand for Organic Foods: What we know and what we need to know”. American Journal of Agricultural Economics, Vol. 80 No. 5, pp.1113-1118.

Thompson, G.D. and J. Kidwell (1998), "Explaining the Choice of Organic Produce, Cosmetic Defects, Prices and Consumer Preferences” American Journal of Agricultural Economics, Vol 80 No. 2, pp. 277-287.

Torjusen H., Sangstad L., O’Doherty Jensen K., \& Kjærnes, U. (2004a): European Consumers' Conceptions of Organic Food: A Review of Available Research. . Oslo: National Institute for Consumer Research, Professional Report No. 4.

Trijp, H.C.M., J-B.E.M. Steenkamp and M.J.J.M. Candel (1997), Quality Labeling as Instument to Create Product Equity: The case of IKB in the Netherlands, Dordrecth: Kluwer Academic Publishers.

Twyford-Jones, P. \& R. Doolan (1998), The International Market for Organic Food. Canberra Organic Growers Society, http://www.pcug.org.au/ jallen/ organic.htm

USDA (1998): Organic Perspectives, FAS Online, http://www.fas.usda.gov/htp2/ organics/1998/june98.htm USDA (1998): Organic Perspectives, FAS Online, http://www.fas.usda.gov/dlp/ circular/2000/0007Dairy/Danish.html van Ravenswaay, E (1986), "How Much Food Safety Do Consumers Want? An Analysis of Current Studies and Strategies for Future Research”, in Clancy, K (ed.), Consumer Demands in the Marketplace, Proceedings of a workshop held in Airlie, Virginia, Oct.27-29, 1986, Resources for the Future, Washington, D.C.

Vogtmann, H. (1988), “Organic Foods: An Analysis of Consumer Attitudes in West Germany”, in Allen, P and D. van Dusen (eds.), Global Perspectives on Agroecology and Sustainable Agrucultural Systems, Proceedings of the Sixth International Scientific Conference of the International Federation of Organic Agriculture Movements, University of California, Santa Cruz.

von Alvensleben, R. (1998), Ecological Aspects of Food Demand: The Case og Organic Food in Germany, http://www.uni-kiel.de:8080/Agraroekonomie/ Abteilungen/agrarmarketing

von Alvensleben, R. and Altmann, M. (1986), „Die Nachfrage nach alternativen Nahrungsmitteln“, Agrarwirtschaft, Vol.35, pp. 289-295.

Weatherell, C., A. Tregear, J. Allinson (2003): In search of the concerned consumer: UK public perceptions of food, farming and buying local. Journal of Rural Studies, 19:233-244.

Wier, M. and C. Calverley (1999), Forbrug af økologiske fødevarer. Del 1: Den økologiske forbruger. (Consumption of Organic Foods, Part 1: The Organic Consumer, in Danish, with English summary). Technical Report No. 272., National Environmental Research Institute, Roskilde.

Wier, M. og C. Calverley (2002): Market Potential for Organic Foods in Europe. British Food Journal 104: 45-62.

Wier, M. Andersen, L.M. and Millock, K. (2005): Information Provision, Consumer Perceptions and Values - the Case of Organic Foods. Forthcoming in: Russell, C. and Krarup, S.: Environment, Information and Consumer Behaviour. New Horizons in Environmental Economics series, Edward Elgar Publ.

Wier, M. Andersen, L.M. and Millock, K. (2004): Perceptions and Consumption of Organic Foods - Trust, Concerns, Values and Behaviour. Working Paper, available at www.akf.dk/organicfoods. 
Will, B. (1998), „Raus aus der Nische. Öko-Produkte auf dem Weg zum Milliardengeschäft“, Lebensmittelzeitung, No.30, pp.36-38.

Zenner, S. \& R. von Ziehlberg (1998), „Der Markt für Bio-Produkte in Österreich“. Working Paper No. 8, Institut für Agrarökonomie der Universität Kiel, Lehrstuhl für Agrarmarketing, Christian-Albrechts University, Kiel. 
Appendix A. Demographic profile of household panels and survey respondents

\begin{tabular}{|c|c|c|c|c|}
\hline & \multicolumn{2}{|c|}{ Great Britain } & \multicolumn{2}{|c|}{ Denmark } \\
\hline \multicolumn{5}{|l|}{ Demographic characteristics } \\
\hline Data & $\begin{array}{l}\text { Total } \\
\text { household } \\
\text { panel, } \\
\text { 2001-2003 }\end{array}$ & & $\begin{array}{l}\text { Total household } \\
\text { panel, } \\
\text { 1997-2001 }\end{array}$ & $\begin{array}{l}\text { Households } \\
\text { in questionnaire } \\
\text { survey }\end{array}$ \\
\hline Total number of households & 20,334 & & 3,611 & 1,609 \\
\hline Average number of households per year & 17,173 & & 2,094 & \\
\hline Households leaving the panel per year (\%) & 21 & & 18 & \\
\hline \multicolumn{5}{|l|}{ Age of main shopper (\%) } \\
\hline$<29$ & 16 & & 15 & 6 \\
\hline 30-39 & 26 & & 22 & 14 \\
\hline $40-49$ & 18 & & 19 & 19 \\
\hline $50-59$ & 17 & & 16 & 23 \\
\hline $60-69$ & 12 & & 15 & 20 \\
\hline $70+$ & 11 & & 13 & 19 \\
\hline \multicolumn{5}{|l|}{ Region (\%) } \\
\hline Capital & 19 & Capital & 23 & 21 \\
\hline North and Scotland & 37 & Eastern region & 31 & 31 \\
\hline South, Midlands and Wales & 44 & Western cities & 27 & 28 \\
\hline & & $\begin{array}{r}\text { Western rural } \\
\text { areas }\end{array}$ & 17 & 20 \\
\hline \multicolumn{5}{|l|}{ Social class (\%) } \\
\hline Upper middle class & $<1$ & & 7 & 6 \\
\hline Middle class & 9 & & 13 & 18 \\
\hline Lover middle class & 32 & & 26 & 25 \\
\hline Skilled working class & 26 & & 32 & 30 \\
\hline Working class+ people on benefit & 32 & & 23 & 21 \\
\hline
\end{tabular}


Appendix B. Top 20 statements over-indexed for organic buyers compared to the average shopper, 2001

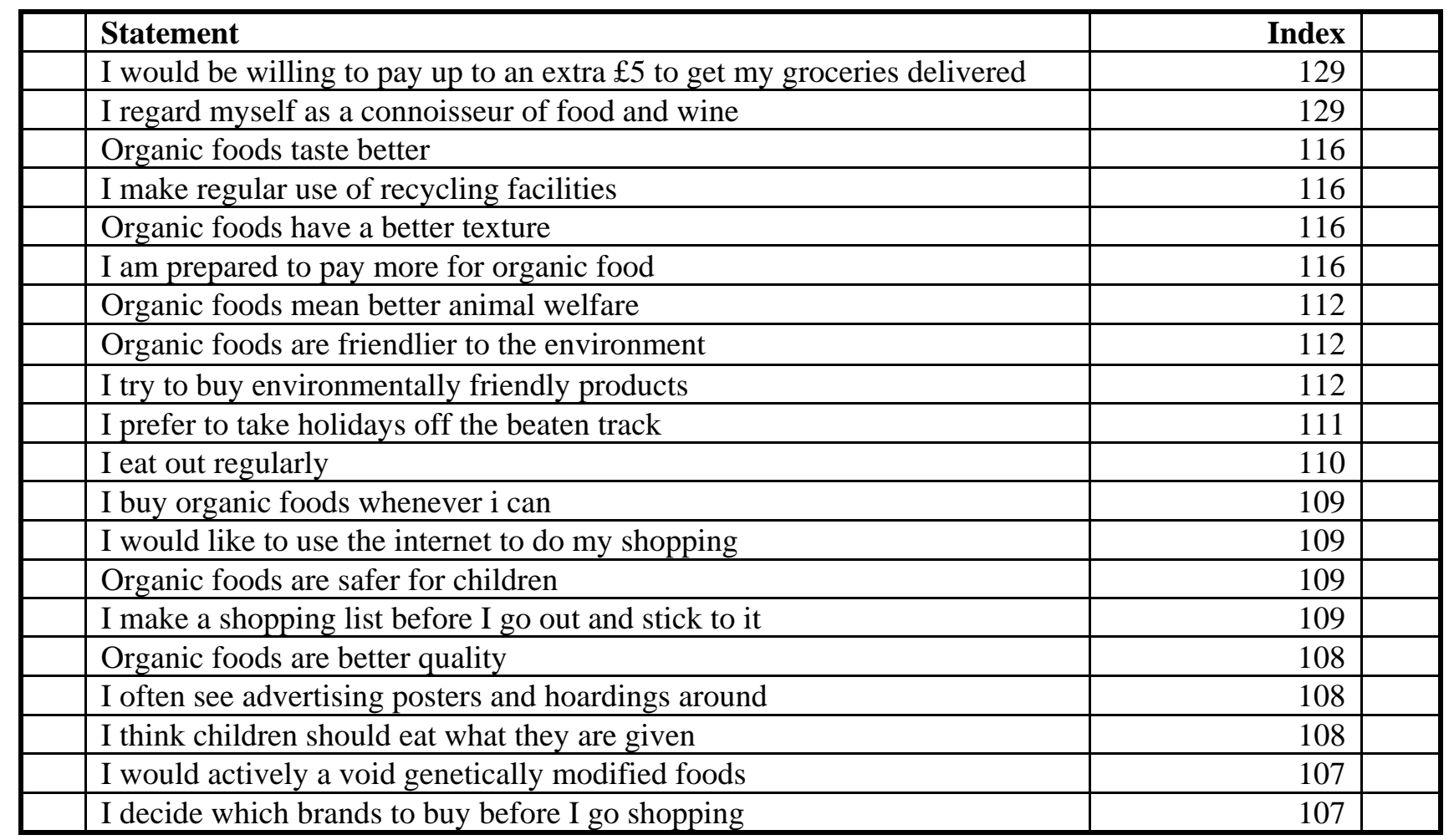

Source: TNS Superpanel Lifestyles, 2001 
Appendix C.

Regression results: model explaining Danish household organic budget share (same model as applied in Table 5), 1997-2001 (1175 households)

\begin{tabular}{|c|c|c|}
\hline & All $\mathrm{f}$ & \\
\hline & Parameter & $\begin{array}{l}\text { Standard } \\
\text { deviation }\end{array}$ \\
\hline Intercept & $1.80^{* *}$ & 0.53 \\
\hline Stated values & & \\
\hline -Stated private values & $0.87 * *$ & 0.09 \\
\hline -Stated public values & $0.21 *$ & 0.09 \\
\hline Purchasing barriers & & \\
\hline -No trust in control of Organic farming & $-0.72 * *$ & 0.14 \\
\hline -No interest inorganic foods (many other things to spend money on) & $-0.68 * *$ & 0.15 \\
\hline -No trust in health effect from eating organic foods & $-0.77 * *$ & 0.14 \\
\hline Not enough knowledge about organic foods & $-1.01 * *$ & 0.14 \\
\hline Pesticide/medicine residue health concern & $0.72 * *$ & 0.12 \\
\hline Region (Western rural is base) & & \\
\hline -Capital area & $2.16^{* *}$ & 0.29 \\
\hline -Eastern Denmark & $0.87 * *$ & 0.27 \\
\hline -Western towns and uplands & $1.42 * *$ & 0.27 \\
\hline Social group (Working class plus people on benefit are base) & & \\
\hline -Upper middle class & $2.14 * *$ & 0.43 \\
\hline -Middle class & $2.26 * *$ & 0.32 \\
\hline -Lower middle class & 0.42 & 0.27 \\
\hline -Skilled working & 0.22 & 0.26 \\
\hline Presence of children (No children is base) & & \\
\hline-1 child & 0.39 & 0.33 \\
\hline-2 children & 0.32 & 0.36 \\
\hline-3 children & -0.37 & 0.61 \\
\hline$-4+$ children & -0.39 & 0.91 \\
\hline Number of adults ( 1 adult is base) & & \\
\hline-2 adults & $-0.77 * *$ & 0.21 \\
\hline-3 adults & $-1.97 * *$ & 0.60 \\
\hline$-4+$ adults & -0.27 & 1.66 \\
\hline Age of key household shopper (less than 30 years is base) & & \\
\hline$-30-39$ & 0.20 & 0.45 \\
\hline$-40-49$ & 0.60 & 0.43 \\
\hline$-50-59$ & 0.37 & 0.43 \\
\hline$-60-69$ & 0.45 & 0.45 \\
\hline$-70+$ & 0.86 & 0.47 \\
\hline
\end{tabular}

Notes:

* Significant at $5 \%$ level

** Significant at $1 \%$ level

Source: Own estimates based on questionnaire and GfK purchase data set, 1997-2001. 